\title{
GENOTYPIC DIFFERENCES BETWEEN TWO MUNGBEAN VARIETIES IN RESPONSE TO SALT STRESS AT SEEDLING STAGE
}

\author{
KANDIL A.A. ${ }^{1}$, ARAFA A.A. ${ }^{2}$, SHARIEF A.E. ${ }^{*}$ AND RAMADAN A.N. ${ }^{3}$ \\ 1Department of Agronomy, Faculty of Agriculture, Mansoura University, Egypt. \\ 2Department of Agricultural Botany, Faculty of Agriculture, Mansoura University, Egypt. \\ ${ }^{3}$ Ministry of Agriculture, Egypt. \\ *Corresponding Author: Email- shariefali42@gmail.com
}

Received: August 23, 2012; Accepted: August 30, 2012

\begin{abstract}
In order to study performance of mungbean to salinity stress, a laboratory experiment was carried out to investigate salinity tolerance of two mungbean varieties (Kawmy-1 and IV 2010) to eight salinity levels i.e. 0, 2, 4, 6, 8, 10, 12 and $14 \mathrm{dS} / \mathrm{m}$ of NaCl concentrations. Mungbean (Vigna radiata (L.) Wilczek) varieties were compared for germination efficiency and seedling characters. Results indicated that mungbean IV 2010 variety recorded the highest percentages of final germination, germination index \%, seedling vigor index, energy of germination, mean germination time (day), coefficient velocity, abnormal seed percentage, root and shoot length, root fresh and dry weight and seedling height reduction. Whilst, mungbean Kawmy-1 variety recorded the highest weight of fresh and dry shoot and relative dry weight. Highest germination parameters and seedling characters of the two studied varieties under control treatment. The obtained results suggested that the two varieties registered a decrease in the percentage of germination and seedlings growth at higher $\mathrm{NaCl}$ concentrations. Results clearly indicated that mungbean Kawme-1 variety appeared to be more tolerant to salt stress than IV 2010 variety recording higher germination parameters and seedling characters. Increasing salinity concentrations significantly reduced germination percentage, seedling vigor index, coefficient of velocity, mean germination time, shoot and root length, shoot and root fresh and dry weight. It could be concluded that germination efficiency i.e. final germination percentage, germination index, energy of germination, mean germination time, abnormal seed percentage, root and shoot length, seedling total fresh and dry weight, dry weight reduction and shoot length reduction were gradually decreased significantly when salinity increased.
\end{abstract}

Keywords- Mungbean varieties, Salinity stress, Germination parameters, Seedling characters, Dry weight reduction and Shoot length reduction

Citation: Kandil A.A., et al (2012) Genotypic Differences between Two Mungbean Varieties in Response to Salt Stress at Seedling Stage. International Journal of Agriculture Sciences, ISSN: 0975-3710 \& E-ISSN: 0975-9107, Volume 4, Issue 7, pp- 278-283.

Copyright: Copyright@2012 Kandil A.A., et al . This is an open-access article distributed under the terms of the Creative Commons Attribution License, which permits unrestricted use, distribution and reproduction in any medium, provided the original author and source are credited.

\section{Introduction}

Salinity became a serious problem for agriculture all over the world. Salinity is one of the major stress factors which limit crop production in most of the arid and semi-arid regions of the world [4]. The extreme increase in population in Egypt needs to increase the total yield of legume crops in order to overcome the lack in protein through summer mungbean cultivation in the newly reclaimed lands especially under saline conditions of such soil. Mungbean (Vigna radiata (L.) Wilczek) is a summer legume crop with short duration (70-90 days) with high nutritive value. In Egyptian, there was shortage in legume summer crop production. Mungbean can be easily grown in the newly reclaimed sandy soil and irrigate by saline water, it can tolerant drought and soil salinity [18]. Therefore, this study was carried out to investigate the varietal seed germination as an important parameter under salinity stresses. Mungbean seed germination is an important parameter which is affected by various factors for example varieties and salinity stress. Crop productivity can be enhanced with optimization germination factors which increase germination rate. The most critical stage in seedling establishment is seed germination that determine fruitful crop production. It is reported by several researchers where there were large differences between introduced varieties in Egypt $[5,7,18]$. Naher and Alam (2010) concluded that highest germination \% was observed in the control treatment of all studied varieties. Germination and seedling growth were reduced under salinity with varying responses for mungbean cultivars $[20,26,28]$. Moreover, salinity may affect mungbean seed germination by producing an outside osmotic potential that avoids water uptake or due to toxic effects of $\mathrm{Na}^{+} \& \mathrm{Cl}^{-}$ ions during seed germination [19,14]. Increasing salinity levels during mungbean seed germination significantly reduced germina- 
tion characters $[2,6,24,26,28]$ and seedling characters $[2,16,17,20,28]$. Keeping in view the above mentioned facts, the present work was conducted to assess performance of some mungbean varieties under different salinity levels and their effect on germination parameters and seedling characters.

\section{Materials and Methods}

This research was conducted in Agronomy Department laboratory, Faculty of Agriculture, Mansoura University, Egypt during March and April 2011 to study the performance of some mungbean (Vigna radiata (L.) Wilczek) varieties to germination under salinity stress and their interactions.

\section{Treatments and Experimental Design}

The experiment was arranged in two factors in factorial experiment in randomized complete block design (RCBD), the first factor included two mungbean (Kawmy-1 and IV 2010) varieties. Seeds of Mungbean (Vigna radiata (L.) Wilczek) varieties i.e. Kawmy-1 and IV 2010 were obtained from National Agricultural Research Centre, Egypt, whereas the second variety was produced from imported lines. The second one included eight different concentrations $(\mathrm{NaCl})$ as presented in Table 1. Seeds of cultivars were surface sterilized by immersion for 5 minutes in sodium hypochlorite solution, then repeatedly washed with deionized water. Twenty five seeds of uniform size in each treatment for each variety were allowed to germinate on a filter paper in $9 \mathrm{~cm}$ diameter petri dishes. Each filter paper was moistened with a water solution at eight different $\mathrm{NaCl}$ concentrations. Distilled water was used as the control solution $(0 \mathrm{dS} / \mathrm{m})$. The $\mathrm{NaCl}$ concentrations were $0,2,4,6,8,10$, 12 and $14 \mathrm{dS} / \mathrm{m}$ of $\mathrm{NaCl}$ which electrical conductivity was measured with a conductivimeter $(\mathrm{dS} / \mathrm{m}=$ deciSiemen per meter). Thus, the whole experiment comprised 64 Petri dishes arranged in factorial experiment randomized complete block design.

Table 1- Salt experimental treatments (concentrations and weight of $\mathrm{NaCl}$ )

\begin{tabular}{lcc}
\hline $\begin{array}{l}\text { Treatments of salt concentration } \\
0 \text { (distilled water as the control) }\end{array}$ & Weight of NaCl & E C dsm-1 \\
\hline $2 \mathrm{dS} \mathrm{m}^{-1} \mathrm{NaCl}$ & - & 0 \\
$4 \mathrm{dS} \mathrm{m}^{-1} \mathrm{NaCl}$ & $1.14 \mathrm{gm} / \mathrm{L}$ (distilled water) & 2 \\
$6 \mathrm{dS} \mathrm{m}^{-1} \mathrm{NaCl}$ & $2.280 \mathrm{gm} / \mathrm{L}$ (distilled water) & 4 \\
$8 \mathrm{dS} \mathrm{m}^{-1} \mathrm{NaCl}$ & $3.440 \mathrm{gm} / \mathrm{L}$ (distilled water) & 6 \\
$10 \mathrm{dS} \mathrm{m}^{-1} \mathrm{NaCl}$ & $4.590 \mathrm{gm} / \mathrm{L}$ (distilled water) & 8 \\
$12 \mathrm{dS} \mathrm{m}^{-1} \mathrm{NaCl}$ & $6.000 \mathrm{gm} / \mathrm{L}$ (distilled water) & 10 \\
$14 \mathrm{dS} \mathrm{m}^{-1} \mathrm{NaCl}$ & $6.900 \mathrm{gm} / \mathrm{L}$ (distilled water) & 12 \\
& $7.980 \mathrm{gm} / \mathrm{L}$ (distilled water) & 14 \\
\hline
\end{tabular}

After pre-treatments of mungbean, seeds were germinated for 14 days, incubating in a growth chamber adjusted to $20 \pm 1{ }^{\circ} \mathrm{C}$ in a dark. For each treatment, 25 seeds were counted at random and placed on a moist germination paper in a Petri dish. There were four replicates for each treatment. Dishes were inspected daily and sterilized water added as required. The number of normal seedlings, abnormal seedlings, dead seeds and hard seed in each replicate was recorded. Every 24 hours the number of germinated seeds was counted. Seeds were categorized as germinated (radical $2 \mathrm{~mm}$ ), hard (no imbibition or swelling) or nonviable (abnormal, dead or infected seeds) as described by ISTA (1993).

Hard seeds can be illustrious from dead seeds by pushing down on each no germinated seed with the flat part of a pencil eraser. If the seed does not crush with gentle pressure, it is considered hard. All seeds which had taken up no water in six days were considered as hard seed. Seeds which at the end of test period are neither hard nor have produced any part of a seedling were considered dead.

Normal seedlings show the potential for continued development into acceptable plants when grown in good quality soil and under promising conditions of moisture, temperature and light, normal and abnormal seedling can documented according to ISTA rules.

Abnormal seedlings do not show the possibility to grow into a standard plant when developed in good quality soil and under positive conditions of moisture, temperature and light.

\section{Studied Characters}

\section{Germination Parameters}

Seedlings were evaluated for:

Final germination percentage: It was calculated according to the germination count taken after 14 days and expressed as percentage according to equation No. (1) which described by Ellis and Roberts (1981) and Ruan, et al (2002):

$$
\text { FGP }=\frac{\text { Number of Germinated Seeds after } 14 \text { Days }}{\text { Number of Germinated Seeds }} \times 100
$$

Germination Index (GI): It was calculated according to equation No.2 [13]:

$$
\mathrm{GI}=\frac{\text { Germination Percentage in each Treatment }}{\text { Germination Percentage in the Control }} \times 100
$$

Seedling vigor index (VI): It was calculated according to Abdul-Baki and Anderson (1973) in the equation No 3:

$$
(V I)=(\text { Average shoot length }+ \text { Average root length }) \times \text { Germination Percentage }
$$

Energy of germination was recorded at the fourth day. Energy of germination was the percentage of germinating seeds 4 days after sowing relative to the number of seeds tested [23].

Mean germination time (MGT): It was determined according to equation No. 4 [8]

$$
M G T=\sum d n / \sum n
$$

Where $(n)$ is the number of seeds which were germinated on day (d), and (d) is the number of days counted from the beginning of germination.

Coefficient of velocity (CV), a unit less parameter determined by a mathematical manipulation that incorporates the number of seeds germinated and the velocity of germination was calculated equation No. (5):

$$
\text { C V }=100\left[\Sigma \mathrm{Ni} / \sum \mathrm{Ni} \mathrm{Ti}\right]
$$

Where $N$ is the number of seeds germinated on day $i$ and $T$ is the number of days from sowing [25]. In general, a higher CV value reflects increased of seed germinated at shorter germination time.

Percentage of abnormal seedling = It was calculated according equation No. (6)

$$
\text { Abnormal seedling }=\frac{\text { Number of abnormal seedling }}{\text { Total number of seeds }}
$$




\section{Seedling Characters}

1. Shoot length: The length of ten seedlings from the seed to the tip of the leaf blade were recorded and expressed in centimeters as the shoot length.

2. Root length: The root length of ten seedlings from the seed to the tip of the root was recorded and expressed in centimeters (cm) as the root length

3. Shoot fresh weight: The weight of ten seedlings was measured and expressed in milligram as the shoot fresh weight.

4. Root fresh weight: The weight of ten seedling roots was measured and expressed in milligram (mg) as the root fresh weight.

5. Root dry weight: The weight of ten seedling roots was recorded and expressed in milligram after oven drying at $70^{\circ} \mathrm{C}$ for $72 \mathrm{~h}$.

6. Shoot dry weight: The weight of ten seedlings was recorded and expressed in milligram after oven drying at $70^{\circ} \mathrm{C}$ for $72 \mathrm{~h}$.

7. Seedling height reduction: The seedling height reduction (SHR) was calculated using the equation No. 7 [12]:

$$
\text { SHR }(\%)=\frac{\text { Plant Height at Control }- \text { Plant Height at Saline Condition }}{\text { Plant Height at Saline Condition }} \times 100
$$

8. Relative dry weight the relative dry weight (RDW) was calculated by using the equation No. 8 [12]

$$
\text { RDW }(\%)=\frac{\text { Total Dry Weight under Saline Condition }}{\text { Total Dry Weight under Control Condition }} \times 100
$$

\section{Statistical Analysis}

All obtained data were statistically analyzed according to the technique of analysis of variance (ANOVA) for factorial experiment in randomized complete block design (RCBD) as published by Gomez and Gomez (1984) with using means of "MSTAT-C" computer software package. Least Significant Difference (LSD) method was used to test the differences between treatment means at 5 and $1 \%$ level of probability as described by Snedecor and Cochran (1980).

\section{Result and Discussion}

\section{Performance of Varieties}

Mungbean IV 2010 variety recorded highest values of final germination percentage, germination index, and seedling vigor index, energy of germination, coefficient velocity, root and shoots length, shoot dry weight, In contrast, mungbean Kawmy-1 variety recorded highest values of mean germination time, abnormal seed percentage, shoot fresh weight, shoot dry weight and relative dry weight. However, root dry weight, root fresh weight and seedling height reduction insignificantly affected by mungbean varieties (Tables 2 and 3). Mungbean IV 2010 variety exceeded Kawmy-1 variety by $10.07 \%, 7.32 \%, 23.1 \%, 10.07 \%, 1.36 \%, 16.96 \%, 27.25 \%, 16.28 \%$, $9.64 \%, 16.28 \%$ and $10.05 \%$, resp. in final germination percentage, germination index, seedling vigor index, energy of germination, mean germination time, coefficient velocity, abnormal seed percentage, shoot length, in root length, shoot fresh weight and seedling height reduction, respectively.
Table 2- Averages of germination percentage (\%), germination index (\%), seedling vigor index, energy of germination, mean germination time, coefficient velocity and abnormal seed percentage

\begin{tabular}{|c|c|c|c|c|c|c|c|}
\hline Treatments & $\begin{array}{c}\text { Final } \\
\text { Germination } \\
\text { percentage } \\
(\%)\end{array}$ & $\begin{array}{c}\text { Germi- } \\
\text { nation } \\
\text { Index } \\
(\%)\end{array}$ & $\begin{array}{l}\text { Seedling } \\
\text { Vigor } \\
\text { Index }\end{array}$ & $\begin{array}{l}\text { Energy of } \\
\text { germina- } \\
\text { tion (\%) }\end{array}$ & $\begin{array}{l}\text { Mean } \\
\text { germina- } \\
\text { tion time } \\
\text { (day) }\end{array}$ & $\begin{array}{c}\text { Coeffi- } \\
\text { cient } \\
\text { velocity } \\
(\%)\end{array}$ & $\begin{array}{c}\text { Abnor- } \\
\text { mal Seed } \\
\text { Percent- } \\
\text { age(\%) }\end{array}$ \\
\hline \multicolumn{8}{|c|}{ A-Cultivars Performance } \\
\hline KAWMY-1 & 72.5 & 75.5 & 977 & 68.5 & 3.07 & 33 & 38.31 \\
\hline IV 2010 & 80.62 & 81.47 & 1271 & 79.62 & 2.62 & 39.74 & 27.87 \\
\hline F- test & ** & ** & ** & ** & ** & ** & $* *$ \\
\hline \multicolumn{8}{|c|}{ B- Salinity levels: } \\
\hline Control & 97.5 & 100 & 2178 & 96 & 2.57 & 44.12 & 8.5 \\
\hline $2 \mathrm{dS} \mathrm{m}^{-1} \mathrm{NaCl}$ & 90.5 & 92.77 & 1816 & 87.5 & 2.46 & 41.32 & 13.5 \\
\hline $4 \mathrm{dS} \mathrm{m}^{-1} \mathrm{NaCl}$ & 83.5 & 85.57 & 1524 & 84 & 2.43 & 40.72 & 17.5 \\
\hline $6 \mathrm{dS} \mathrm{m}^{-1} \mathrm{NaCl}$ & 79 & 81.01 & 1290 & 79 & 2.58 & 37.06 & 22 \\
\hline $8 \mathrm{dS} \mathrm{m}^{-1} \mathrm{NaCl}$ & 75.5 & 77.35 & 883 & 75 & 2.86 & 35.77 & 36.75 \\
\hline $10 \mathrm{dS} \mathrm{m}^{-1} \mathrm{NaCl}$ & 69 & 70.73 & 672 & 64.5 & 2.83 & 34.7 & 42 \\
\hline $12 \mathrm{dS} \mathrm{m}^{-1} \mathrm{NaCl}$ & 61.5 & 63.05 & 405 & 61 & 3.15 & 31.48 & 54.5 \\
\hline $14 \mathrm{dS} \mathrm{m}^{-1} \mathrm{NaCl}$ & 56 & 57.42 & 223 & 45.5 & 3.87 & 25.55 & 70 \\
\hline F-Test & ** & ** & ** & ** & ** & ** & ** \\
\hline L.S.D $5 \%$ & 3.47 & 3.35 & 192.75 & 4.07 & 0.21 & 2.86 & 10.78 \\
\hline L.S.D 1\% & 4.63 & 4.48 & 257.45 & 5.44 & 0.28 & 3.82 & 14.4 \\
\hline \multicolumn{8}{|c|}{ C. Interaction Effects } \\
\hline F- test & N.S. & N.S. & N.S & $* *$ & ** & ** & N.S \\
\hline
\end{tabular}
as affected by cultivars and salinity stress.

N. S. $=$ Not significant, ${ }^{*}=$ significant at $5 \%,{ }^{* *}=$ significant at $1 \%$

Table 3- Averages of shoot length (cm), root length (cm), shoot and root fresh weight (gm), shoot and root dry weight (gm), seedling height reduction (\%) and relative dry weight (\%) as affected by

\begin{tabular}{|c|c|c|c|c|c|c|c|c|}
\hline Treatments & $\begin{array}{l}\text { Shoot } \\
\text { length } \\
(\mathrm{cm})\end{array}$ & $\begin{array}{l}\text { Root } \\
\text { length } \\
(\mathrm{cm})\end{array}$ & $\begin{array}{l}\text { Shoot } \\
\text { fresh } \\
\text { weight } \\
\text { (gm) }\end{array}$ & $\begin{array}{l}\text { Root } \\
\text { fresh } \\
\text { weight } \\
\text { (gm) }\end{array}$ & $\begin{array}{l}\text { Shoot } \\
\text { dry } \\
\text { weight } \\
\text { (gm) }\end{array}$ & $\begin{array}{l}\text { Root } \\
\text { dry } \\
\text { weight } \\
\text { (gm) }\end{array}$ & $\begin{array}{l}\text { Seedling } \\
\text { height } \\
\text { reduction } \\
(\%)\end{array}$ & $\begin{array}{c}\text { Relative } \\
\text { dry } \\
\text { weight } \\
(\%)\end{array}$ \\
\hline \multicolumn{9}{|c|}{ A-Cultivars Performance: } \\
\hline KAWMY-1 & 6.07 & 6.37 & 2.64 & 0.596 & 0.441 & 0.061 & 107.12 & 77.91 \\
\hline IV 2010 & 7.65 & 7.05 & 2.21 & 0.643 & 0.325 & 0.087 & 96.35 & 69.61 \\
\hline F- test & ** & . & ** & N.S & ** & N.S & N.S & ** \\
\hline \multicolumn{9}{|c|}{ B- Salinity levels } \\
\hline Control & 11 & 11.32 & 2.91 & 0.99 & 0.517 & 0.189 & 0 & 0 \\
\hline $2 \mathrm{dS} \mathrm{m}^{-1} \mathrm{NaCl}$ & 9.73 & 10.23 & 2.84 & 0.95 & 0.47 & 0.095 & 14.6 & 90.66 \\
\hline $4 \mathrm{dS} \mathrm{m}^{-1} \mathrm{NaCl}$ & 8.48 & 9.76 & 2.61 & 0.86 & 0.432 & 0.09 & 33.21 & 84.55 \\
\hline $6 \mathrm{dS} \mathrm{m} \mathrm{m}^{-1} \mathrm{NaCl}$ & 7.64 & 8.63 & 2.47 & 0.63 & 0.412 & 0.082 & 46.41 & 79.94 \\
\hline $8 \mathrm{dS} \mathrm{m}^{-1} \mathrm{NaCl}$ & 6.13 & 5.55 & 2.38 & 0.55 & 0.376 & 0.065 & 95.5 & 71.28 \\
\hline $10 \mathrm{dS} \mathrm{m}^{-1} \mathrm{NaCl}$ & 5.24 & 4.38 & 2.24 & 0.38 & 0.337 & 0.04 & 124.76 & 65.51 \\
\hline $12 \mathrm{dS} \mathrm{m}^{-1} \mathrm{NaCl}$ & 3.99 & 2.53 & 2.08 & 0.31 & 0.277 & 0.024 & 181.01 & 53.37 \\
\hline $14 \mathrm{dS} \mathrm{m}^{-1} \mathrm{NaCl}$ & 2.68 & 1.29 & 1.89 & 0.24 & 0.239 & 0.01 & 319.1 & 44.77 \\
\hline F- Test & ** & ** & $* *$ & ** & ** & ** & $* *$ & ** \\
\hline L.S.D 5\% & 0.98 & 1.38 & 0.3 & 0.27 & 0.059 & 0.089 & 91.87 & 10.1 \\
\hline L.S.D 1\% & 1.31 & 1.85 & 0.4 & 0.37 & 0.079 & 0.119 & 122.72 & 13.5 \\
\hline \multicolumn{9}{|c|}{ Interaction Effects: C- } \\
\hline F- test & N.S & N.S & N.S & N.S & N.S & N.S & ** & N.S \\
\hline
\end{tabular}
mungbean cultivars and salinity stress.

N. S. $=$ Not significant, ${ }^{*}=$ significant at $5 \%,{ }^{* *}=$ significant at $1 \%$

Results indicated that mungbean kawmy-1 variety exceeded IV 2010 by $16.28 \%, 26.30 \%, 10.65 \%$ and $10.65 \%$ in relative dry weight, shoot fresh weight, shoot dry weight and relative dry weight, respectively. Several investigators such as Ashour, et al (1992); El Kramany (2002); Mohamed and El Kramany (2005). Naher and Alam (2010) reported that there were great differences between introduced varieties and concluded that highest germination \% was observed in the control treatment of all studied varieties. Win, et al (2011) suggested that genetically diverse arrange- 
ments resistant to salt stresses within mungbean varieties due to substantial practical value for studying the mechanism of salt tolerance and for the delivery of genetic resources for salinity in breeding program. So, the differences between mungbean cultivars in final germination index might be due to the genetically factors and heredity variation among the two cultivars under study. These results are in good accordance with those found by Salah Uddin, et al (2009); Singh, et al (2006).

\section{Salinity Stress Effects}

The results clearly indicate that increasing salinity levels significantly increased abnormal seed percentage and seedling height reduction (Tables 2 and 3 ). The results showed that increasing salinity levels to $2,4,6,8,10,12$ and $14 \mathrm{dS} / \mathrm{m} \mathrm{NaCl}$ significantly reduced the final Seedling vigor index by 16.6, 30.0, 40.7, 59.4, 69.1, 81.4 and $89.7 \%$, resp. as compared with the control treatment. Increasing salinity levels to $2,4,6,8,10,12$ and $14 \mathrm{dS} / \mathrm{m} \mathrm{NaCl}$ significantly reduced energy of germination by 18.22, 12.50, 17.70, 21.80, $32.81,36.45$ and $52.60 \%$, resp. compared with the control treatment. Moreover, increasing salinity levels to 2, 4, 6, 8,10,12 and 14 $\mathrm{dS} / \mathrm{m} \mathrm{NaCl}$ significantly reduced main germination time compared with the control treatment. Increasing salinity levels to 2, 4, 6, 8, 10, 12 and $14 \mathrm{dS} / \mathrm{m} \mathrm{NaCl}$ significantly reduced coefficient velocity by $1.66,5.47,7.18,15.20,14.80,24.53$ and $38.60 \%$, resp. compared to the control treatment. In addition, increasing salinity levels to 2 , $4,6,8,10,12$ and $14 \mathrm{dS} / \mathrm{m} \mathrm{NaCl}$ significantly reduced final abnormal seed percentage by $13.50,17.50,22.00,36.75,42.00,54.50$ and $70.0 \%$, resp. as compared with the control treatment. Saline condition reduces the ability of seed to absorb water, causing rapid reduction in germination rate and induces many metabolic changes. Germination reduction under salinity stress may be due to this fact that dormancy increases in crop seeds under salinity stress [15]. On the other hand, mungbean seed germination may be affected by salinity through either creating external osmotic potential or toxic effect of $\mathrm{Na}^{+}$and $\mathrm{Cl}^{-}$ions $[14,19]$. Babbar and Dhingra (2007) reported that seed germination was decreased with increasing level of salinity, reduction being maximum in $\mathrm{Km}-4$ variety and least in Km-2 variety. Length of plumule and radicle also got reduced with increasing salinity and decrease was maximum in Asha and minimum in $\mathrm{Km}-2$ variety for both parameters. These results are in good accordance with those reported by Ahmed (2005); Ruan, et al (2002); Salah Uddin, et al (2009) and Singh, et al (2006).

Increasing salinity levels to $2,4,6,8,10,12$ and $14 \mathrm{dS} / \mathrm{m} \mathrm{NaCl}$ significantly reduced root length by $9.62,13.78,23.76,50.97$, $61.30,77.65$ and $88.60 \%$, resp. as compared to the control treatment. Increasing salinity levels to $2,4,6,8,10,12$ and $14 \mathrm{dS} / \mathrm{m}$ $\mathrm{NaCl}$ significantly reduced shoot length by $11.5,22.90,30.54$, $44.27,52.36,63.7$ and $75.6 \%$, resp. as compared with the control treatment. Increasing salinity levels to 2, 4, 6, 8, 10, 12 and $14 \mathrm{dS} /$ $\mathrm{m} \mathrm{NaCl}$ significantly reduced shoot fresh weight by $2.40,10.30$, $15.12,18.20,23.00,28.52$ and $35.0 \%$, resp. as compared with the control treatment. Furthermore, increasing salinity levels to 2, 4, 6, $8,10,12$ and $14 \mathrm{dS} / \mathrm{m} \mathrm{NaCl}$ significantly reduced root fresh weight by $4.0,13.13,36.36,44.44,61.61,68.68$ and $75.75 \%$, resp. as compared with the control treatment. Increasing salinity levels to 2 , $4,6,8,10,12$ and $14 \mathrm{dS} / \mathrm{m} \mathrm{NaCl}$ significantly reduced shoot dry weight by $9.0,16.44,20.30,27.27,34.81,46.42$ and $53.77 \%$, resp. as compared with the control treatment. Moreover, increasing salinity levels to $2,4,6,8,10,12$ and $14 \mathrm{dS} / \mathrm{m} \mathrm{NaCl}$ significantly reduced root dry weight by 49.7, 52.3, 56.6, 65.6, 78.8, 87.3 and $94.7 \%$, resp. as compared with the control treatment. However, increasing salinity levels to $2,4,6,8,10,12$ and $14 \mathrm{dsm}^{-1}$ significantly increased seedling height reduction. Furthermore, increasing salinity levels to $2,4,6,8,10,12$ and $14 \mathrm{dS} / \mathrm{m} \mathrm{NaCl}$ significantly reduced relative dry weight by $9.34,18.45,20.06,28.72,34.49$, 46.63 and $58.23 \%$, resp. as compared to the control treatment. It seems that reduction in seedling fresh weight may be due to decreasing water uptake by seedling under salinity. Salt decreases the osmatic water potential, creating a water stress in seedlings. Reduction in mungbean under salt stress resulted from combination of ions toxicity and altered water relation that caused large accumulation of sodium and magnesium ions and reduced calcium and potassium concentration, transpiration, stomatal conductance and hydraulic conductance decreased as salinity increased [22]. Naher and Alam (2010) reported that highest germination \% was observed in the control treatment of all varieties. Higher $\mathrm{NaCl}$ concentrations and sowing BARI Mung 4 variety significantly reduced than other varieties. All the varieties showed similar performances at higher $\mathrm{NaCl}$ concentration considering yield contributing character. In addition, salinity may affect seed germination by generating an external osmotic potential that averts water uptake or due to toxic effects of $\mathrm{Na}^{+}$and $\mathrm{Cl}$ - ions on seed germination $[14,19]$. These results are in agreement with those concluded by Ahmed (2005); Babbar and Dhingra (2007); Misra and Gupta (2006); Mohammed (2007) and Win, et al (2011).

\section{Interaction Effects}

With respect to the interaction between mungbean cultivars and salinity concentration, the results showed that there was a significant interaction effect between mungbean cultivars and salinity stress concentrations on energy of germination (\%), mean germination time (day) coefficient velocity (\%) and seedling height reduction (\%). The results clearly showed that highest values of energy of germination, mean germination time and coefficient velocity were obtained from sowing IV 2010 variety and without salinity stress as shown in Fig.'s 1, 2 and 3. Seedling height reduction was significantly affected due to the interaction between mungbean cultivars and salinity concentrations. The results revealed that increasing salinity levels significantly reduced energy germination percentage and coefficient velocity percentage of the two varieties. IV 2010 variety recorded highest energy germination percentage and coefficient velocity (\%) than Kawmy-1 under all salinity levels. However, Kawmy-1 recorded highest mean germination time (day) and seedling height reduction than IV 2010 variety under all salinity levels. However, increasing salinity levels significantly increased both mean germination time and seedling height reduction of both varieties after salinity level of $6 \mathrm{dS} / \mathrm{m} \mathrm{NaCl}$. Minimum value of seedling height reduction was recorded with sowing IV 2010 variety and salinity level of $2 \mathrm{dS} / \mathrm{m} \mathrm{NaCl}$, which was 10.62. Meanwhile, a highest value of seedling height reduction was 205.02 reselected from sowing Kawmy-1 variety and salinity levels of $12 \mathrm{dS} / \mathrm{m} \mathrm{NaCl}$ (Fig. 4). This might be due to the varietal response of mungbean varieties to salinity. Hossain, et al (2005) reported that Binamoog-2 and mutant E5 M511 varieties showed better performance on almost all the parameters under the salinity treatments despite drastic reduc- 
tions in those parameters. The mutant N5 J521 showed less tolerance to imposed salinity of 3.7 and $7.8 \mathrm{dS} / \mathrm{m}$. Similar results were reported by Ahmed (2005); Naher and Alam (2010); Promila and $\operatorname{Kumar}(2000)$.

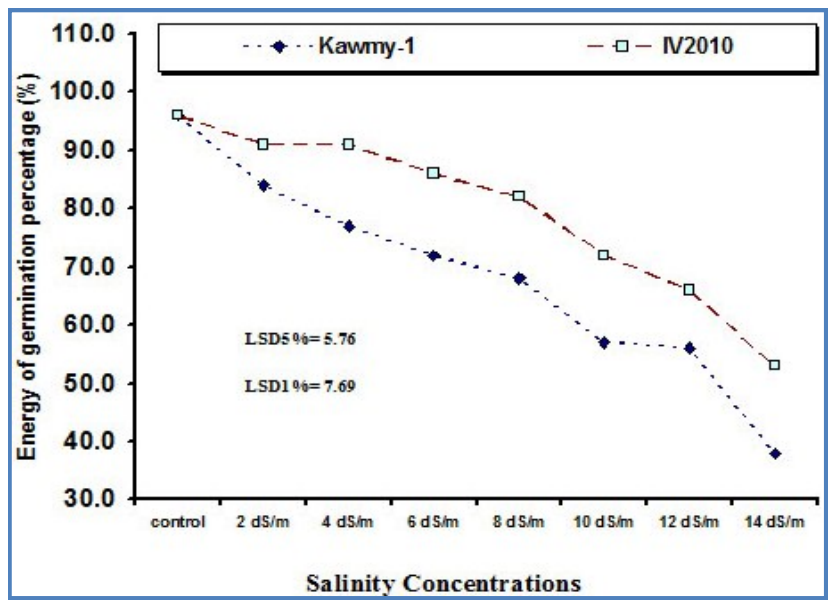

Fig. 1- Averages of energy of germination percentage (\%) as effected by the interaction between cultivars and salinity stress

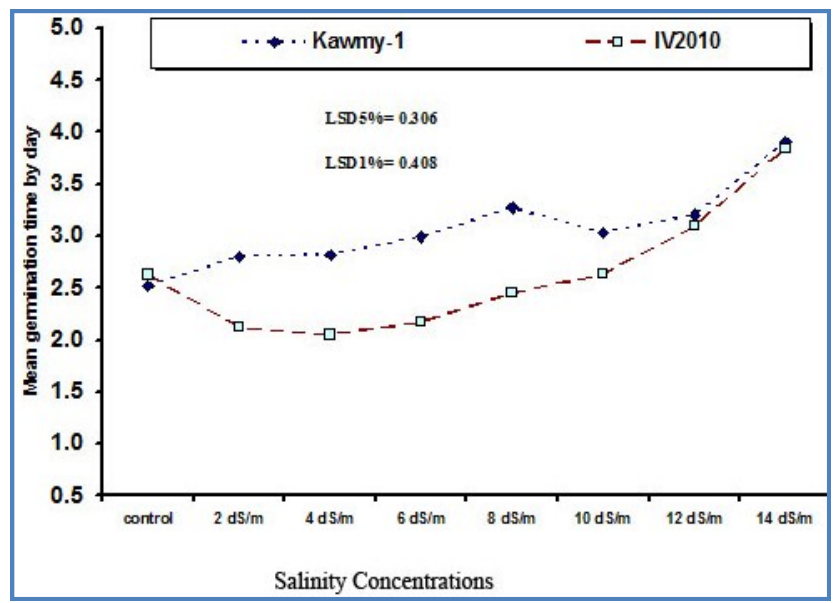

Fig. 2- Averages of mean germination time by day as effected by the interaction between cultivars and salinity stress

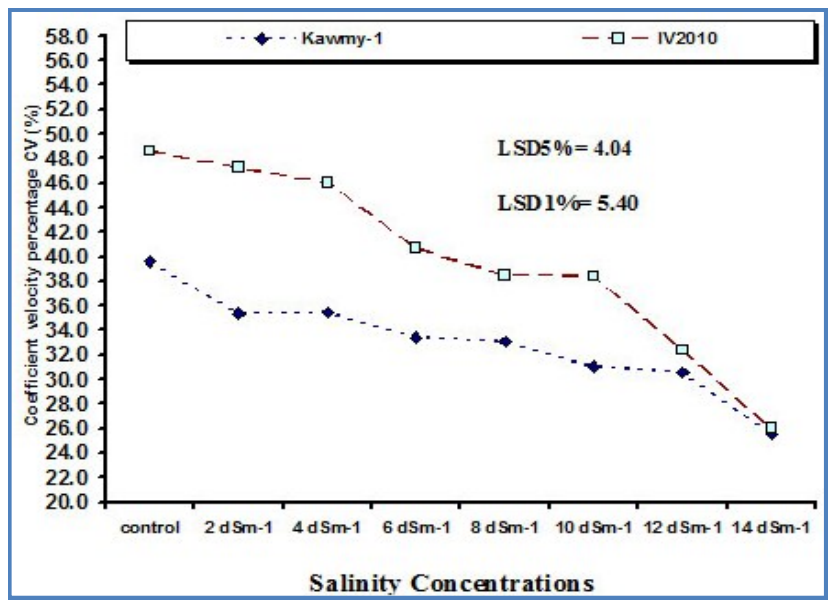

Fig. 3- Averages of coefficient velocity percentage (\%) as effected by the interaction between cultivars and salinity stress

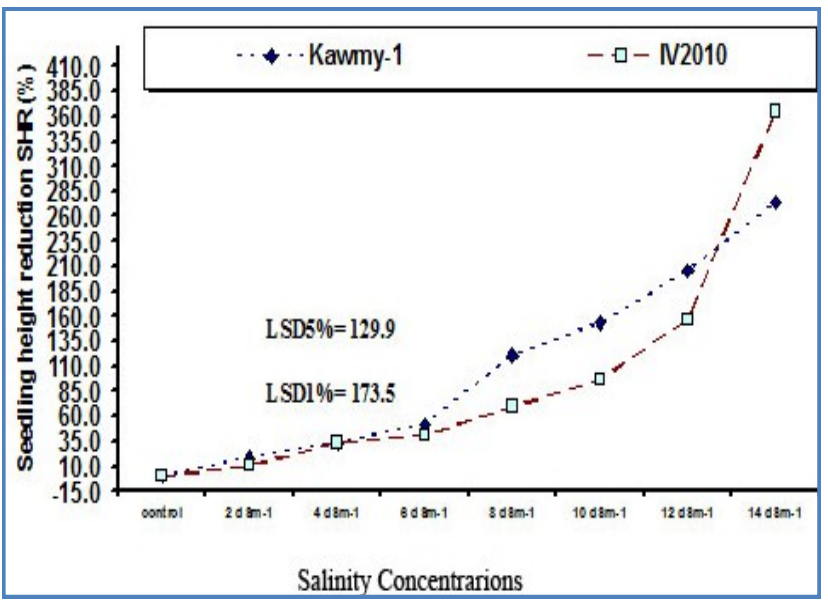

Fig. 4- Averages of seedling height reduction (\%) as effected by the interaction between cultivars and salinity stress

\section{Conclusion}

So, from all the obtained results it could be concluded that maximum mungbean seed germination percentage and seedling parameters under salinity stress are produced by sowing kawmy-1 variety with increasing salinity concentrations levels up to $14 \mathrm{dS} / \mathrm{m}$ $\mathrm{NaCl}$. This variety was more tolerant to salinity and recommended to be used in breeding program for enhancing mungbean cultivation in newly reclaimed soils.

\section{References}

[1] Abdul-Baki A.A. and Anderson J.D. (1973) Crop Sci., 13, 630633.

[2] Ahmad S., Wahid A., Rasul E. and Wahid A. (2005) Bot. Bull. Acad. Sin., 46, 135-142.

[3] Ahmed S. (2005) Int. J. Biol. Biotechnol., 2, 483-488.

[4] Anwer M., Hussain I., Alam S.S. and Baig F. (2001) Pakistan Journal of Biological Sciences, 4(2), 124-127.

[5] Ashour N.I., Behairy T.G., El Lateef E.M.A. and Selim M.M. (1992) 5th Conference on Agronomy, Zagazig University, Egypt, 361-370.

[6] Babbar K.R.S. and Dhingra H.R. (2007) Haryana Agric. Univ. J. Res., 37, 1-6.

[7] El Kramany M.F. (2002) Egypt J. Applied Sci., 17, 218-227.

[8] Ellis R.H. and Roberts E.H. (1981) Seed Sci. Technol., 9, 373409.

[9] Gomez K.A. and Gomez A.A. (1984) Statistical procedures for agricultural research, 2nd edition, New York, 680.

[10]Hossain M.S., Islam M.T. and Prodhan A.K.M.A. (2005) Bangladesh J. Train. Dev., 18, 123-127.

[11]ISTA (1993) Seed Sci. Technol., 21, 1-285.

[12]Islam M.M. and Karim M.A. (2010) The Agriculturists., 8(2), 5765.

[13]Karim M.A., Utsunomiya N. and Shigenaga S. (1992) Japan. J. Crop Sci., 61, 279-284. 
[14]Khajeh-Hosseini M., Powell A.A. and Bingham I.J. (2003) Seed Sci. Technol., 31, 715-725.

[15]Mahdavi B. and Sanavy S.A. (2007) Pakistan Journal of Biological Sciences, 10(2), 273-279.

[16]Misra N. and Gupta A.K. (2006) American Journal of Plant Physiology, 1(1), 1-12.

[17]Mohammed A.H.M.A. (2007) Res. J. Agric. Biol. Sci., 3, 200213.

[18]Mohamed M.H. and El Kramany (2005) J. Applied Sci. Res., 1, 78-84.

[19]Murillo-Amador B., Lopez-Aguilar R., Kaya C., LarrinagaMayoral J. and Flores-Hernandez A. (2002) J. Agronomy Crop Sci., 188, 235-247.

[20]Naher N. and Alam A.K.M.M. (2010) Int. J. Sustain Crop Prod., $5,8-11$.

[21]Promila K. and Kumar S. (2000) Biol. Plant., 43, 423-426.

[22]Raptan P.K., Hamid A., Khaliq Q.A., Solaiman A.R.M., Ahmed J.U. and Karim M.A. (2001) Korean J. Crop Sci., 46, 387-394.

[23]Ruan S., Xue Q. and Tylkowska K. (2002) Seed Sci. Technol., $30,61-67$.

[24]Salah Uddin A.K.M., Amin R., Ullah J. and Asaduzzman Md. (2009) Am. Eur. J. Agron., 2, 180-184.

[25]Scott S.J., Jones R.A. and William W.A. (1984) Crop Sci., 24, 1192-1199.

[26]Singh J., Mathur N., Bohra S., Bohra A. and Vyas A. (2006) Am. Eur. J. Agric. Environ. Sci., 1, 48-50.

[27]Snedecor G.W. and Cochran W.G. (1980) Statistical Methods, 7th Ed., 507.

[28]Win K.T., Oo A.Z, Hirasawa T., Ookawa T. and Yutaka H. (2011) Afr. J. Biotechnol., 10, 1615-1624. 